I) 'Pure' water of the channel Dek Nullah,

II) Wastewater of Ravi Rayon Limited,

III) Wastewater of Ittehad Chemicals, and

IV) Dek Nullah 'polluted' water after the discharge into it of wastewater from two industries, namely Ravi Rayon Limited and Ittehad Chemicals.

The analysis of these waters showed that sample I was the best in quality (medium-salinity and low-sodium water: C2-S1), sample II was of the quality class C3-S1 (high-salinity and low-sodium water), sample III was found to be of the poorest quality (very-high-salinity and very-high-sodium water: C4-S4), while sample IV was of relatively bad quality (high-salinity and mediumsodium water: C3-S2). Only the wastewater of Ittehad Chemicals had some sediment in it, the qualitative analysis of which showed the presence of oxalates, sodium, iron, and magnesium.

The study of planktonic biota in Dek Nullah 'pure' and 'polluted' waters showed that they were more diverse in the former than in the latter; indeed, unless Bacteria are classed as fauna, there was no representative of these last in the 'polluted' water.

The industrial wastewater effluents are being discharged into Dek Nullah, and this 'polluted' water is being used for irrigation by the farmers operating along its downstream course. The effects of this water on Rice germination were studied, and it was found that such germination was significantly greater in Dek Nullah 'pure' water than in its 'polluted' water.

Dek Nullah 'polluted' water may deteriorate further with time, as more and more wastes are added to it, and it may have deleterious effects on soils when used for irrigation purposes-causing salinity and sodicity problems unless proper management techniques are adopted.

\section{REFERENCES}

AMERICAN PUBLIC HEALTH ASSOCIATION (1976). Standard Methods for the Examination of Water and Wastewater (14th edn). American Public Health Association, Washington, DC: xxxix + 1193 pp., illustr.

AYERS, A. D. \& HAYWARD, H. E. (1948). A method for measuring the effects of soil salinity on seed germination with observations on several crop-plants. Proc. Soil Sci. Soc. Amer., 13, pp. 224-6.

AYERS, R. S. \& WESTCOT, D. W. (1976). Water Quality for Agriculture. Irrigation and Drainage Paper 29, FAO, Rome, Italy: xiii +97 pp., illustr.
AYERS, A. D., BROWN, J. W. \& WADLEIGH, C. H. (1952). Salt tolerance of barley and wheat in soil plots receiving several salinization régimes. Agron. J., 44, pp. 307-10.

AZIZ, J. A. \& SHEIKH, M. I. (1974). Biological Treatment of a Local Paper-mill Waste. Report No. 004-04-74, Institute of Public Health Engineering and Research, University of Engineering and Technology, Lahore: 6 pp., (mimeogr.).

DEWEY, D. R. (1960). Salt tolerance of twenty-five strains of Agropyron. Agron. J., 52, pp. 631-5.

El-ZAHAB, A. A. A. (1971). Salt tolerance of eight Egyptian cotton varieties, I: At germination stage. Z. Acker und Pflanzenbau, 133, pp. 299-307.

GEORGE, L. Y. \& WILLIAMS, W. A. (1964). Germination and respiration of Barley, Strawberry Clover and Ladino Clover seeds in salt solutions. Crop Sci., 4, pp. 450-2.

HAYWARD, H. E. \& BERNSTEIN, L. (1958). Plant growth relationship on salt-affected soils. Bot. Rev., 24, pp. 548 635.

HAYWARD, H. E. \& WADLEIGH, C. H. (1949). Plant growth on saline and alkali soils. Advan. Agron., 1, pp. 1-38.

KHAN, S. S. \& SHEIKH, K. H. (1976). Effects of different levels of salinity on seed germination and growth of Capsicum annuum L. Biologia, 22, pp. 15-25.

PAINTER, H. A. (1971). Chemical, physical and biological characteristics of wastes and waste effluents. Pp. 329-60 in Water and Water Pollution Handbook Vol. 1 (Ed. L. L. Ciaccio). Marcel Dekker, New York, NY: xix + 449 pp., illustr.

RAINWATER, F. H. \& THATCHER, L. L. (1960). Methods for Collection and Analysis of Water Samples. U.S. Geological Survey, Water-supply Paper No. 1454, U.S. Government Printing Office, Washington, DC: ix +301 pp., illustr.

RHOADES, J. D. \& BERNSTEIN, L. (1971). Chemical, physical and biological characteristics of irrigation and soil water. Pp. 141-222 in Water and Water Pollution Handbook Vol. 1 (Ed. L. L. Ciaccio). Marcel Dekker, New York, NY: xix +449 pp., illustr.

SCARPINO, P. V. (1971). Bacterial and viral analysis of water and wastewater. Pp. 639-751 in Water and Water Pollution Handbook Vol. 2 (Ed. L. L. Ciaccio). Marcel Dekker, New York, NY: ix +800 pp., illustr.

SHEIKH, K. H. \& IRSHAD, M. (1980). Wastewater effluents from a tannery: their effects on soil and vegetation in Pakistan. Environmental Conservation, 7(4), pp. 319-24, 2 figs.

U.S.D.A. (1954). Diagnosis and Improvement of Saline and Alkali Soils. Agriculture Handbook No. 60, U.S. Government Printing Office, Washington, DC: vii +160 pp., illustr.

VOGEL, A. 1. (1957). A Textbook of Macro and Semimicro Qualitative Inorganic Analysis (4th edn.). Longmans, Green, London, England, UK: xv +663 pp., illustr.

WILHM, J. F. (1975). Biological indicators of pollution. Pp. $375-400$ in River Ecology (Ed. B. A. Whitton). Blackwell Scientific Publications, Oxford, England, UK: $x+725 \mathrm{pp}$., illustr.

\title{
International Environmental Management Seminars
}

An inquiry was recently conducted by the Center for Education in International Management (Centre d'Etudes Industrielles), Conches, Geneva, among environmental mangers in Europe and elsewhere, to determine the new focus of interest after seven years of offering courses on Environmental Management. Apparently this interest falls into two main categories:

1) Specific technological issues such as Toxic Substance Control and Hazardous Waste Disposal, and

2) Topics of Methodological and Social Orientation such as Environmental Impact Assessment.
The Center has, therefore, decided to run two consecutive one-week seminars next year, which can be at tended either separately or together, in order to meet the specific interests of different participants. The seminars will be from 1-5 and 8-12 February 1982 .

Application forms and further details can be obtained from the undersigned:

Michael G. Royston, Programme Coordinator IEMS Center for Education in International Management 4 Chemin de Conches, 1231 Geneva

Switzerland. 